\title{
Comparison Performance of Nine Level Multilevel Inverter Using Bipolar and Unipolar Switching Schemes
}

\author{
Maaspaliza Azri ${ }^{1, *}$, Azrita Alias ${ }^{1,2}$, Musa ${ }^{1}$, Akmal Afiq Nazmudi ${ }^{1}$, Zulhani Rasin ${ }^{1,2}$ \\ ${ }^{1}$ Faculty of Electrical Engineering, Universiti Teknikal Malaysia Melaka (UTeM), Melaka, Malaysia \\ ${ }^{2}$ Center for Robotics and Industrial Automation (CeRIA), Universiti Teknikal Malaysia Melaka, Melaka, Malaysia
}

Received July 29, 2019; Revised December 17, 2019; Accepted December 24, 2019

Copyright $\odot 2019$ by authors, all rights reserved. Authors agree that this article remains permanently open access under the terms of the Creative Commons Attribution License 4.0 International License

\begin{abstract}
Multilevel inverter structures have the advantages due to the ablility to operate at high dc-bus voltage. It is able to operate at higher power applications by using series connection of switching devices. In addition, multilevel inverter can generate output voltage with very low harmonic distortion and synthesis a staircase voltage waveform by having multiple voltage levels. Various multilevel inverter topologies are introduced; however, cascaded multilevel inverter is commonly used because it is easy to be implemented. In addition, multilevel inverter topologies are able to operate at lower switching frequency and it produces higher efficiency by producing lower switching dissipation. In this paper, MATLAB/Simulink is used to model the seven levels cascaded multilevel PWM inverter by using bipolar and unipolar switching techniques. The analysis of the cascaded multilevel inverter will be done on different types of non-linear loads such as R-load, RL-load and RC-load The THD of voltages and currents on each type of loads that are done and finally the results are compared.
\end{abstract}

Keywords Multilevel Inverter, PWM Inverter, H-bridge, Bipolar and Unipolar, Total Harmonic Distortion

\section{Introduction}

Inverters are circuits that are used to convert the direct current power such as solar panels and batteries to alternate current power at a desired output voltage and frequency. Inverters are commonly used in application which requires variable voltage and frequency alternating current supply. Some of these applications are speed control of direct current motor, cell phones and the most popular device used is Uninterruptible Power Supplies (UPS) as well as running alternating current appliances from an automobile battery [1].

In the past, the conventional inverters such as square wave inverter are widely used due to its simplicity. Although it is simple to construct, it introduces substantial higher order harmonic values in the line current. Harmonic results in decreasing live cycle of electrical equipment and the power quality. Moreover, the harmonic contents around the switching sidebands can produce mechanical vibration in electrical machines depending on their frequencies and magnitude, acoustic noise and overheating of the core of distribution transformers [2, 7-8, 12-13].

They are able to generate output voltage and draw input current with very low distortion by increasing the number of output levels. In addition, they generate smaller common-mode voltage, thus reducing stress in the motor bearings [3, 10]. Fig. 1, Fig. 2 and Fig. 3 show the three most common MLI topologies which are classified into neutral point clamped MLI (NPC-MLI), flying capacitor MLI (FC-MLI) and cascaded H-Bridge MLI (CHB-MLI) respectively $[4,11]$. 


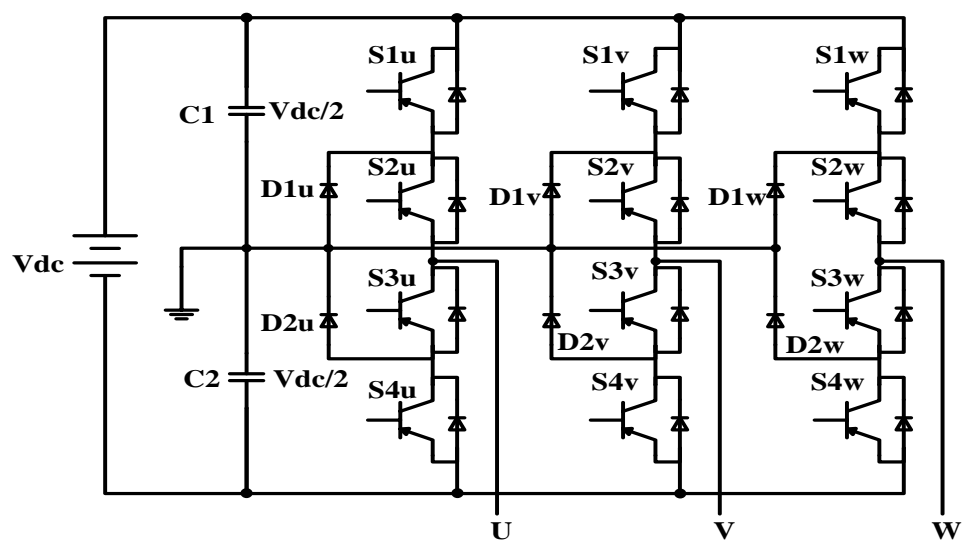

Figure 1. Neutral Point Clamped Topology [4]

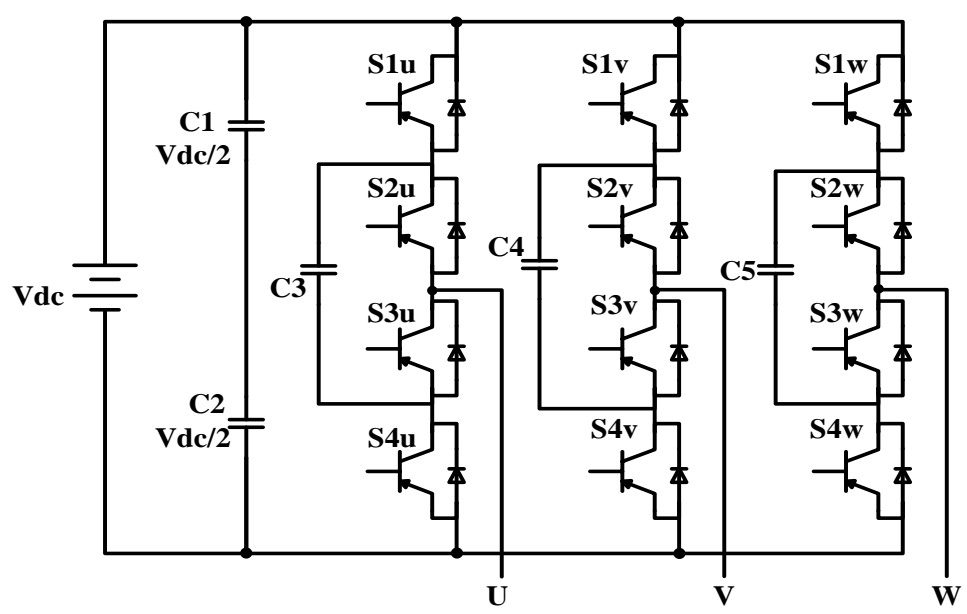

Figure 2. Flying Capacitor Topology [5]

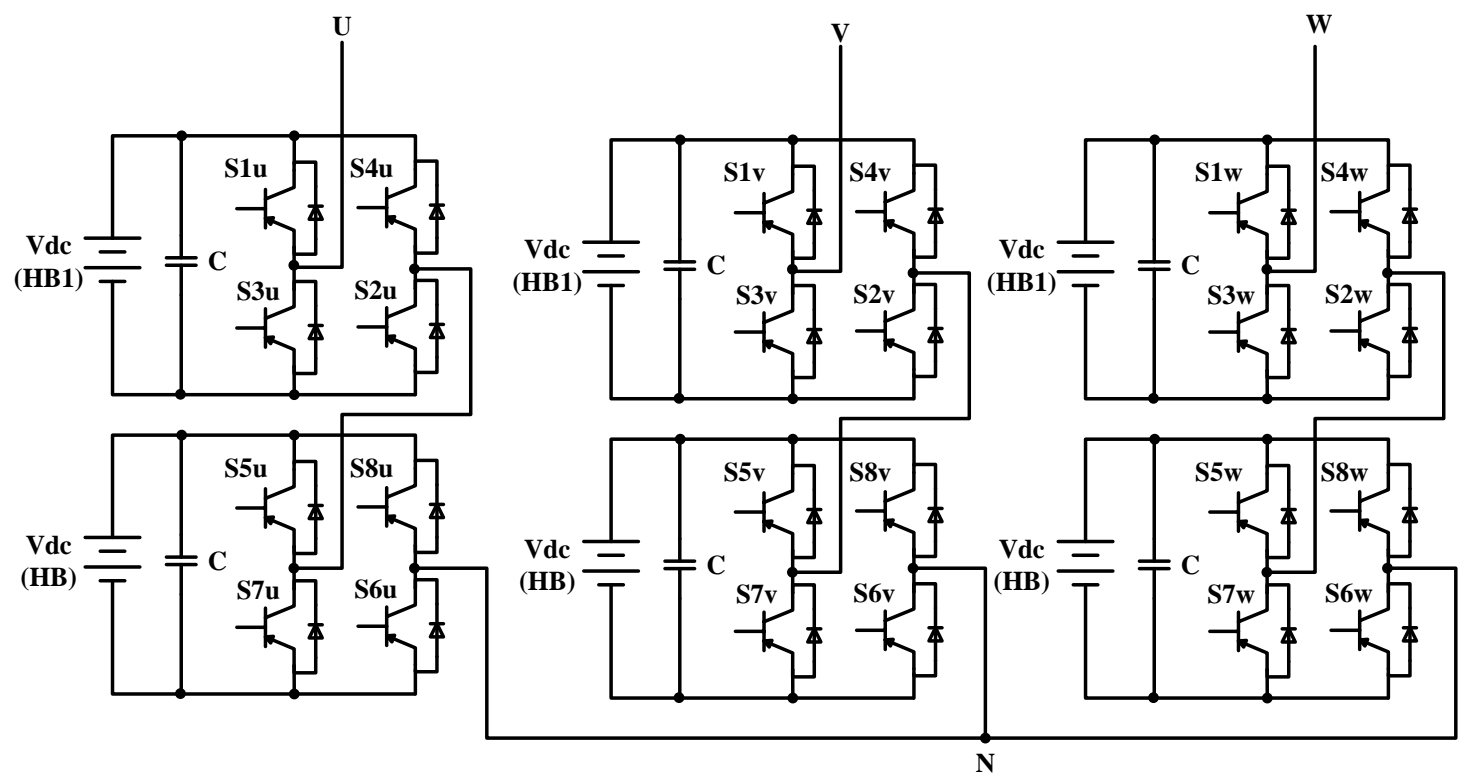

Figure 3. Cascaded H-bridge Topology [5] 
The multilevel inverters are different in circuit structures and the components used. Among of these three topologies, cascaded H-bridge cell is most often to be used due to its minimum components used, reliability and modularity [4]. In this study, the three-phase seven-level multilevel inverter is designed by using SPWM bipolar and unipolar switching schemes. Unipolar switched inverters have the advantage of higher efficiency due to reduced switching loss and low iron loss of inductor in output filter. In addition, the distortion of output current is quite significant in low power levels. However, bipolar switched inverters are able to reduce low frequency harmonics especially at low power level [2]. Fig. 4 shows the block diagram of three-phase nine-level multilevel inverter.

Multicarrier PWM technique is widely used due to easy implementation, low harmonic output and low switching losses. Multilevel SPWM needs multiple carriers. Level-shifted PWM such as phase disposition (PD) technique is used due to lead less distorted line voltages since all the carriers are in phase [5]. The signal configuration for PD technique is showed in Fig. 5. The inverter dc bus voltage is usually fixed while its ac output voltage can be adjusted by either bipolar or unipolar modulation schemes [6].

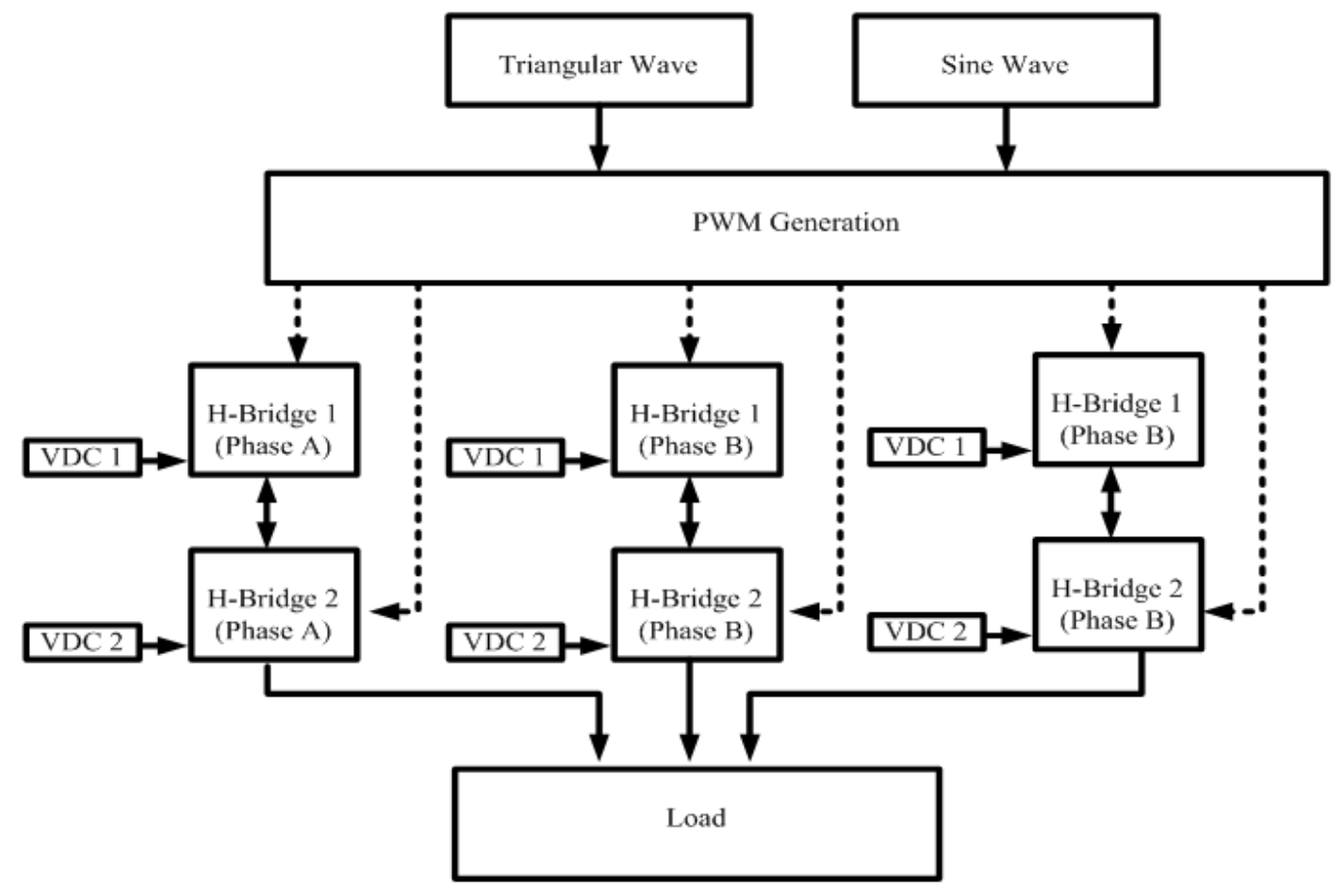

Figure 4. Block Diagram of Nine-Level Multilevel Inverter

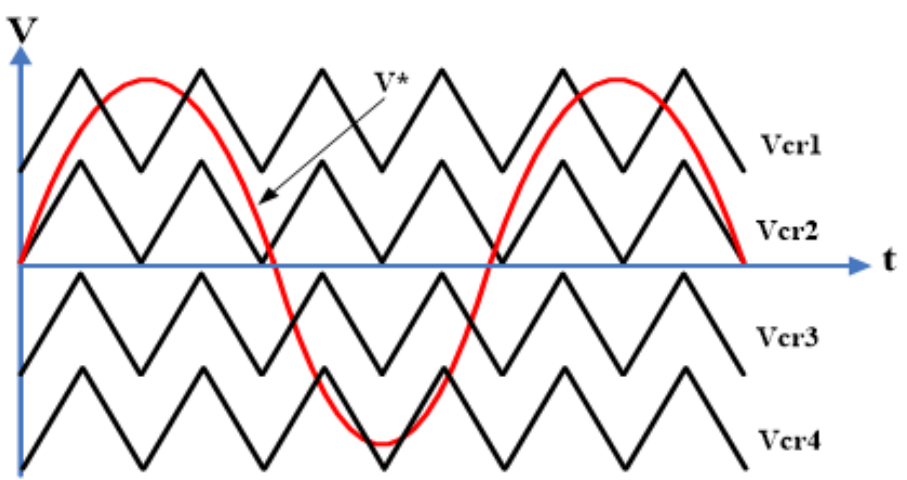

Figure 5. Phase dissipation (PD) technique 
Control of the switches for sinusoidal PWM output requires a reference signal and carrier signal. Frequency modulation $\left(m_{f}\right)$, and amplitude modulation, ma should be considered when using PWM. The mf can be calculated using (1). $m_{f}$ should be an odd integer and an integer to avoid the existing of sub-harmonics at output voltage. $m_{f}$ should be a multiple of 3 for three-phase PWM inverter. Increasing the carrier frequency increases the frequencies at which the harmonics occur.

$$
m_{f}=\frac{f_{\text {carrier }}}{f_{\text {reference }}}=\frac{f_{\text {tri }}}{f_{\text {sin }}}
$$

The amplitude modulation can be calculated as equation. If $0 \leq m_{a} \leq 1$, the fundamental output voltage is calculated as illustrated in (2) and (3).

$$
m_{a}=\frac{V_{m, \text { reference }}}{V_{c, \text { carrier }}}=\frac{V_{m, \text { sin }}}{V_{c, \text { tri }}}
$$

$$
V_{1}=m_{a} V_{d c}
$$

\section{Simulation Model}

This section will explain the model of three phase seven level multilevel inverter modeling and unipolar and bipolar PWM techniques.

Fig. 6 shows MATLAB Simulink model of nine levels multilevel inverter. It consists of six single phase full bridge inverters. From signal generator, four carrier waveforms are produced and all are in phases. The signal reference is placed at the middle of the carrier sets. The generating signals are produced by using unipolar and bipolar pulse width modulation (PWM) respectively. The simulation parameters for these both studies are showed in Table 1.

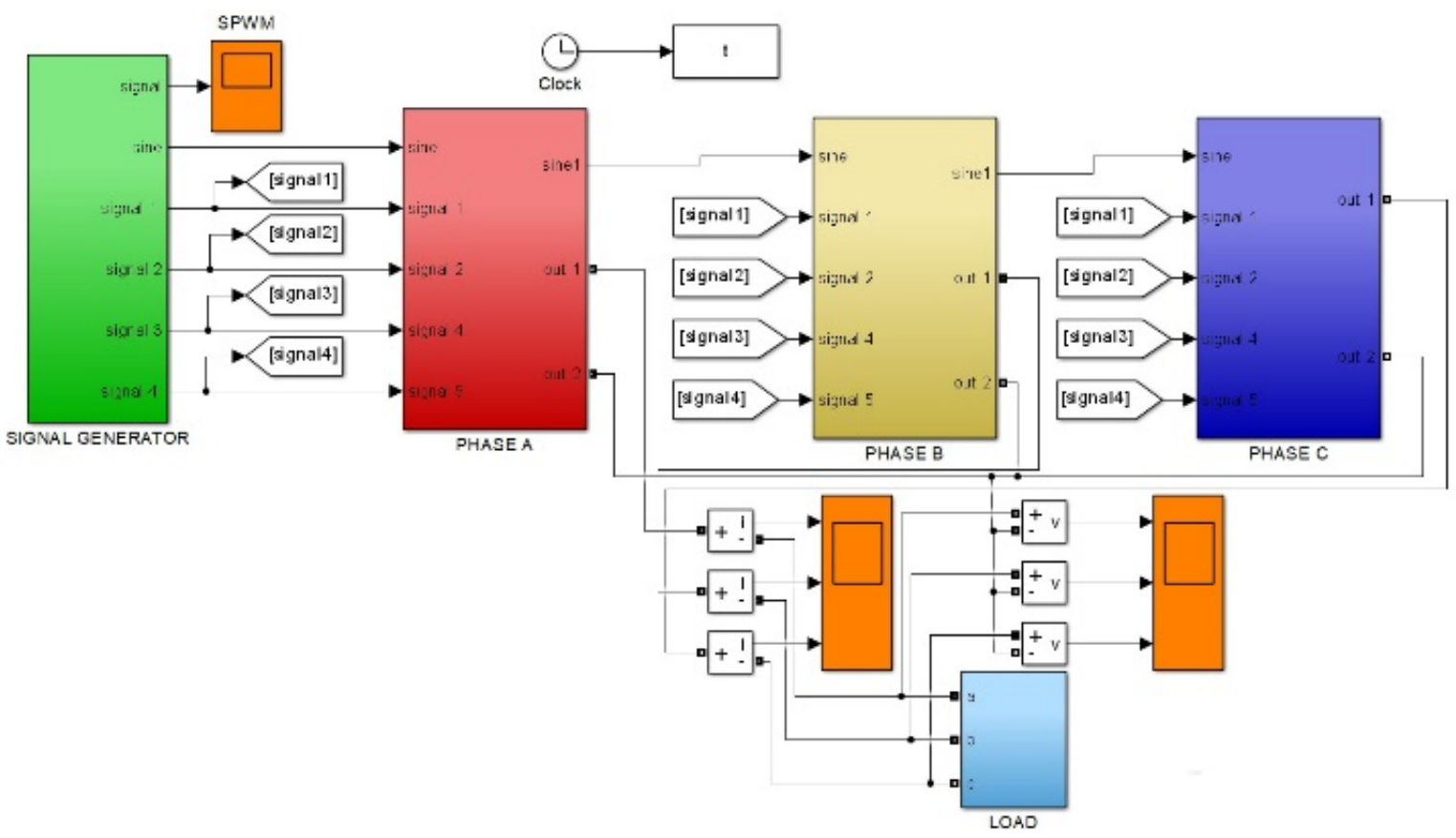

Figure 6. MATLAB Simulink model of seven levels multilevel inverter

Table 1. Simulation Parameter

\begin{tabular}{cc}
\hline Parameter & Value \\
\hline Vdc1 for H-Bridge 1 & $100 \mathrm{~V}$ \\
\hline Vdc2 for H-Bridge 2 & $100 \mathrm{~V}$ \\
\hline Carrier Frequency & $5 \mathrm{kHz}$ \\
\hline Reference Frequency & $50 \mathrm{~Hz}$ \\
\hline Ouput Voltage (Vp) & $200 \mathrm{~V}$ \\
\hline R Load & $100 \Omega$ \\
\hline C Load & $30 \mu \mathrm{F}$ \\
\hline L Load & $20 \mathrm{mH}$ \\
\hline
\end{tabular}




\subsection{Unipolar PWM Technique}

Fig. 7A and Figure 7B show the unipolar PWM compensator signal of the upper and lower single phase full bridge inverter respectively.

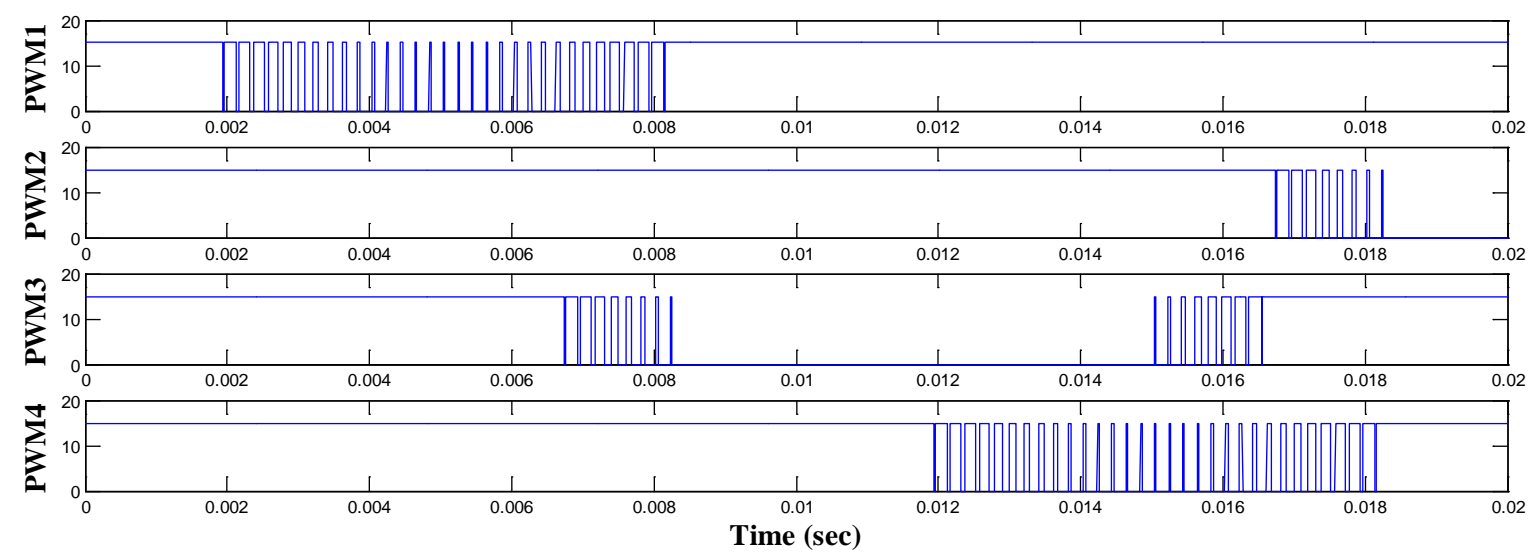

(a)
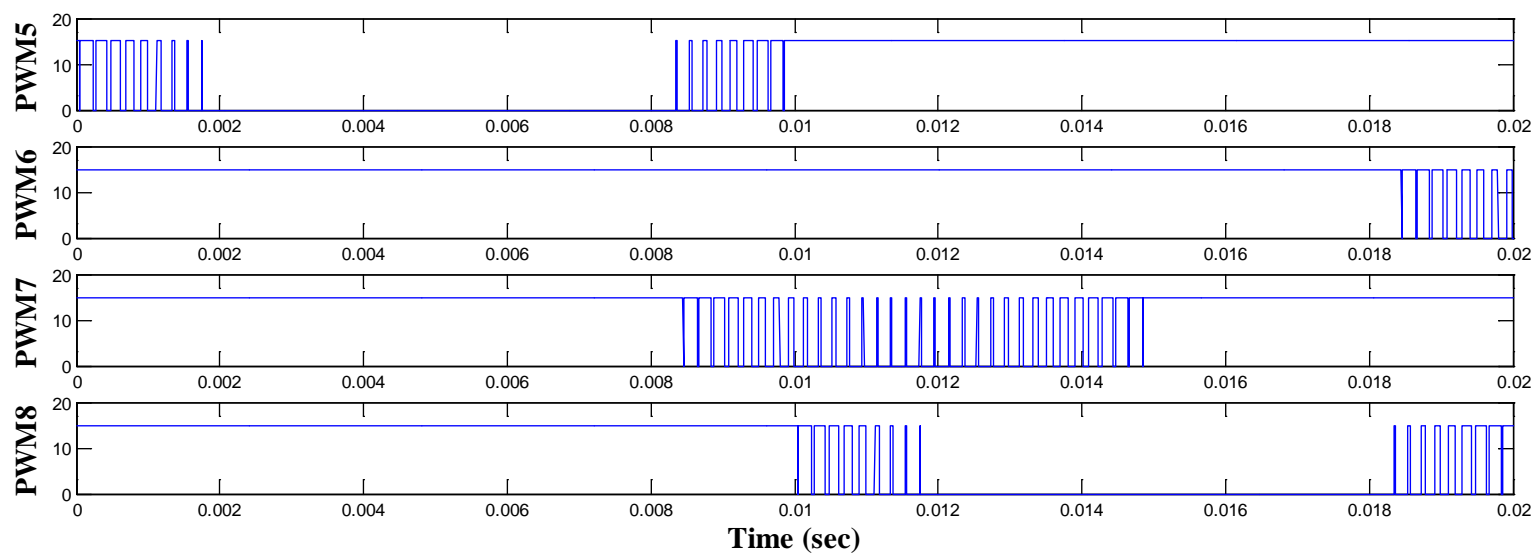

(b)

Figure 7. (a) PWM Compensator Signal (Upper), (b) PWM Compensator Signal (Lower)

\subsection{Bipolar PWM Technique}

Fig. 8A and Fig.8B show bipolar PWM compensator signal of the upper and lower single phase full bridge inverter respectively.

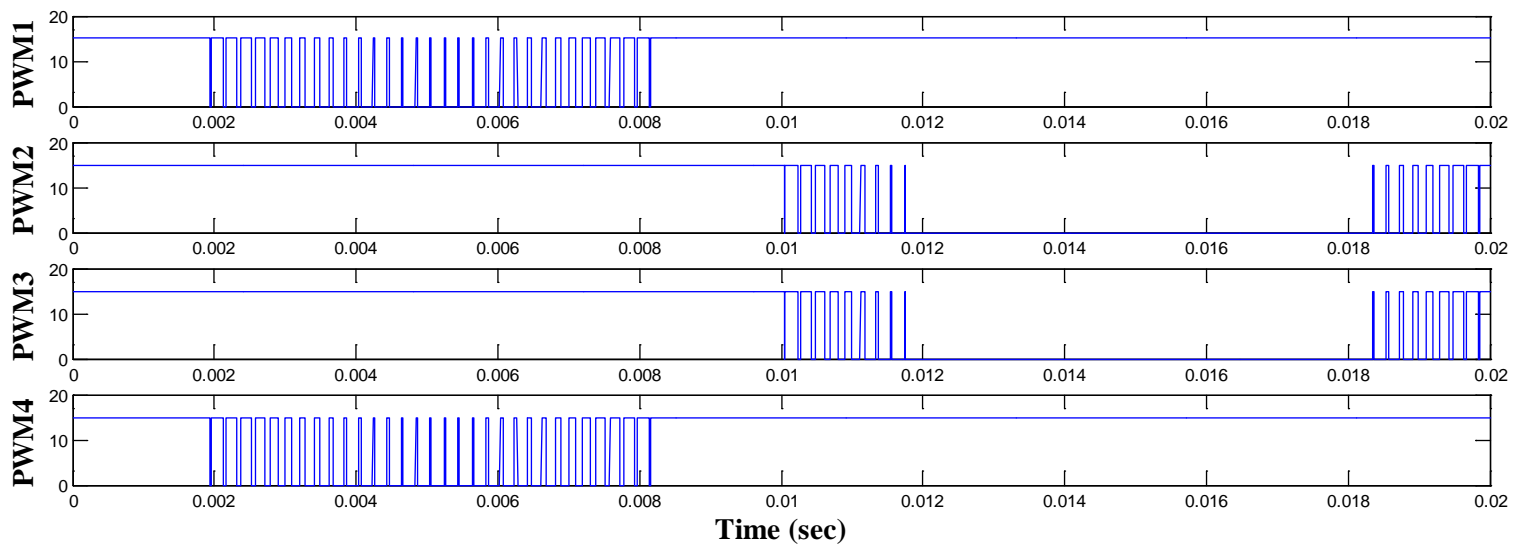

(a) 


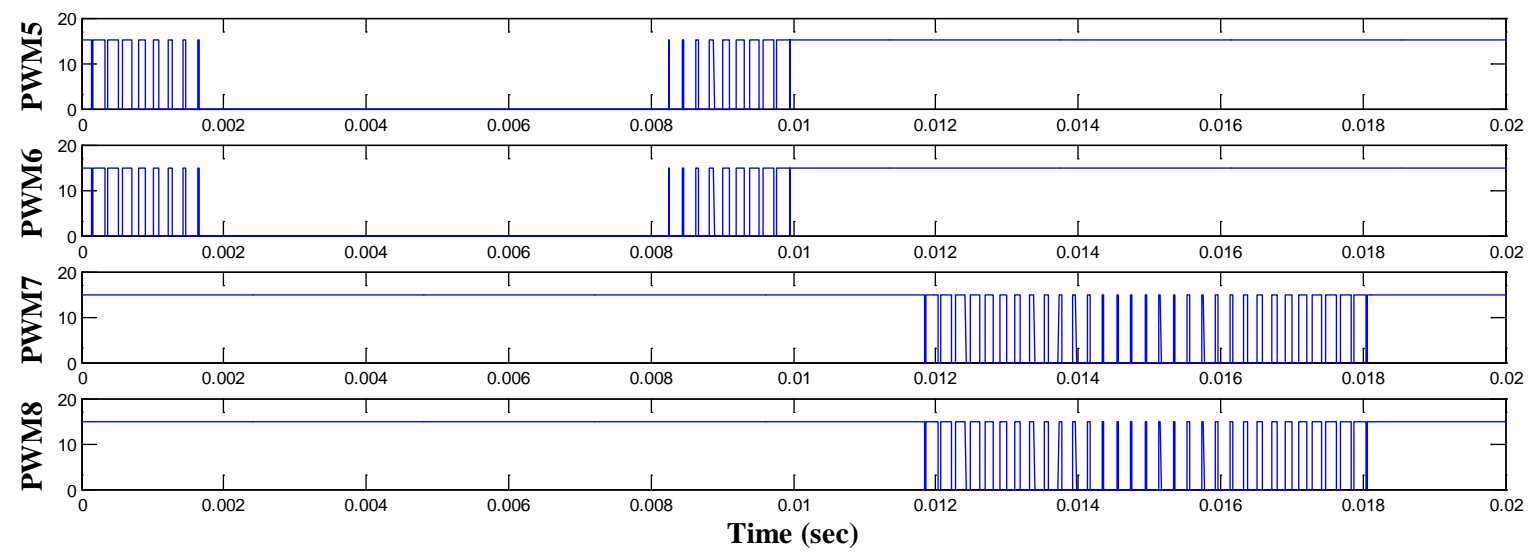

(b)

Figure 8. (a) PWM Compensator Signal (Upper), (b) PWM Compensator Signal (Lower)

\section{Results and Analysis}

In seven levels of multilevel inverter, two single phase full bridge inverters are connected in series to form three legs of phase of three phase inverters. There are many types of non-linear loads such as R-load, RL-load and RC-load. Each type of loads has different output voltages and currents waveforms as well as having different harmonic distortion values. MATLAB/Simulink is used to simulate the unipolar PWM and Bipolar inverter switching schemes for different types of non-linear loads.

\subsection{R load with Unipolar PWM Technique}

Each leg of inverters is connected to R load $(100 \Omega)$ and DC voltage $(100 \mathrm{~V})$. The three phase currents and voltages are plotted respectively as well as the total harmonic distortion of current and voltage as shown in Fig. 9 and Fig. 10.
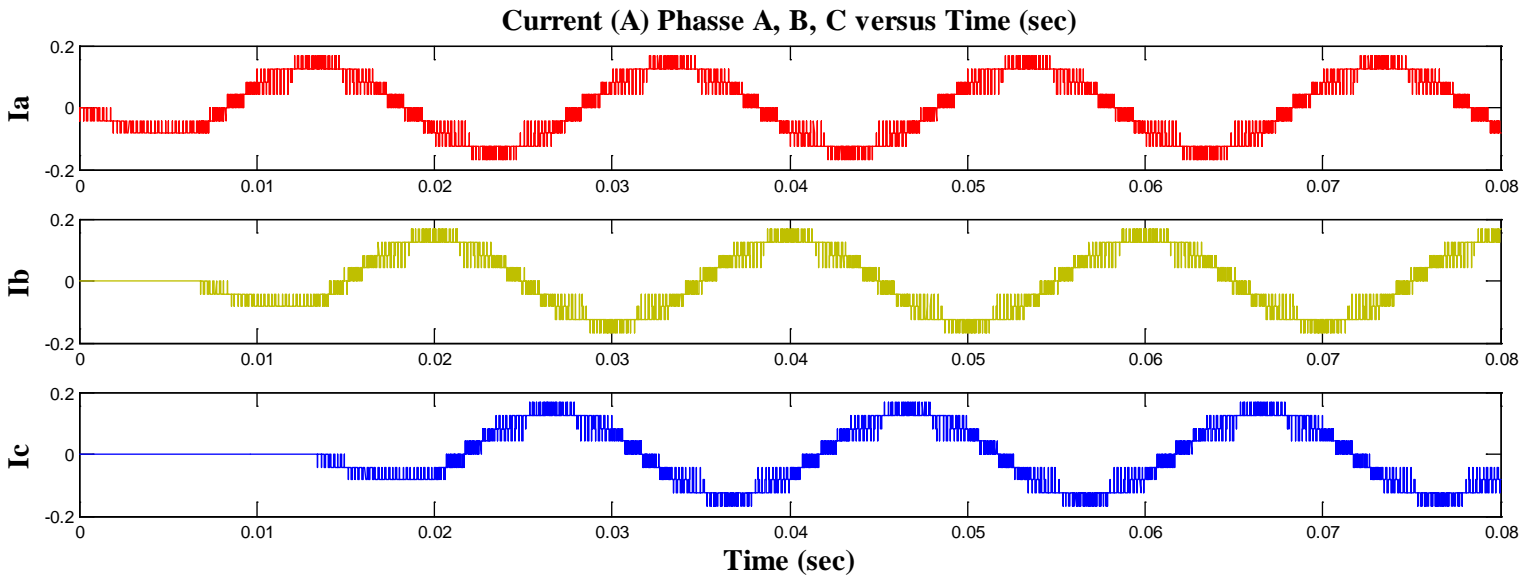

(a) 


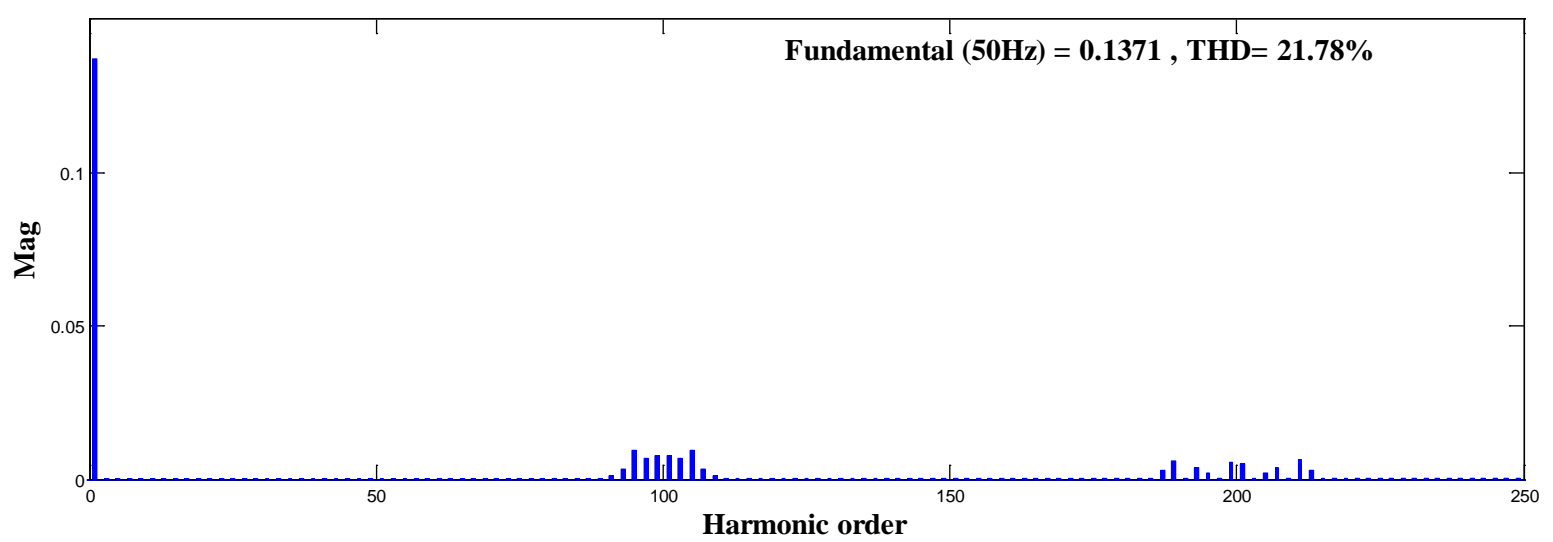

(b)

Figure 9. (a) Three Phase Current (R-load), (b) THD for Phase Current (R-load)
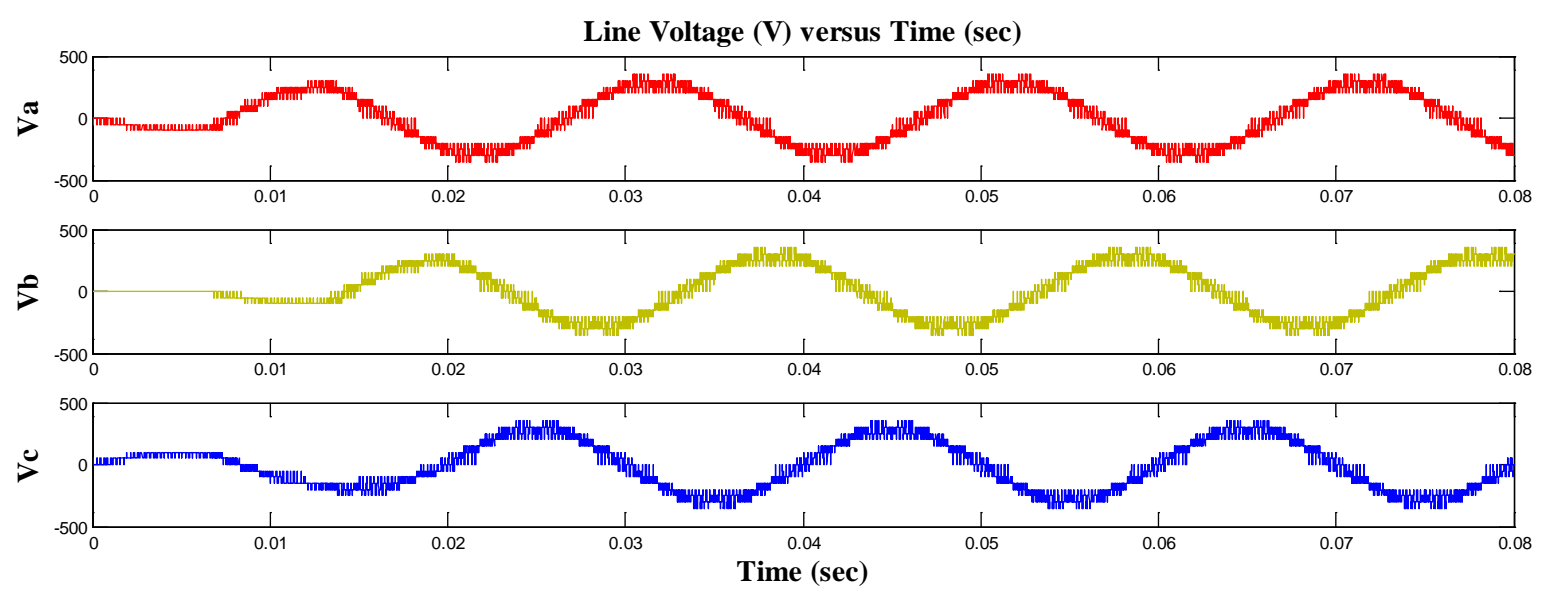

(a)

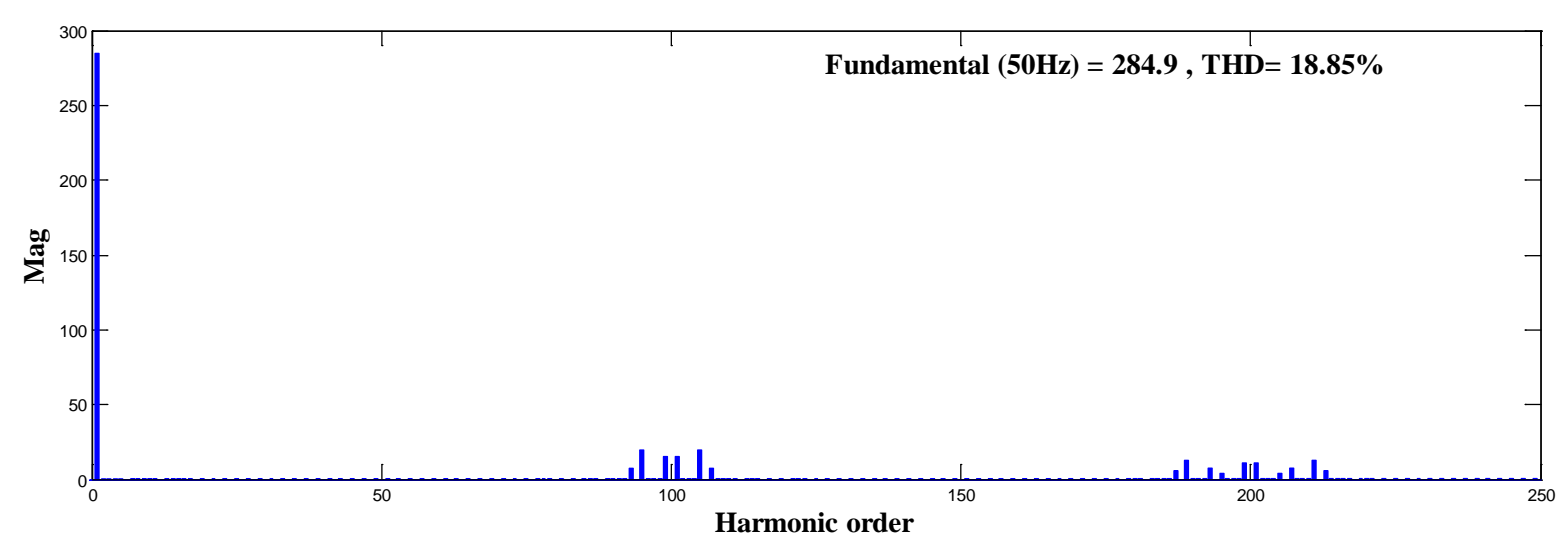

(b)

Figure 10. (a) Line-to-neutral Voltage (R-load), (b) THD for Phase Voltage (R load)

\subsection{RL load with Unipolar PWM Technique}

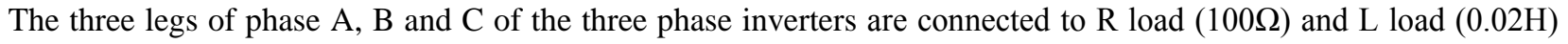
respectively. The three phase currents and voltages are plotted respectively and total harmonic distortion of current and voltage is show in Fig. 11 and Fig. 12 respectively. 

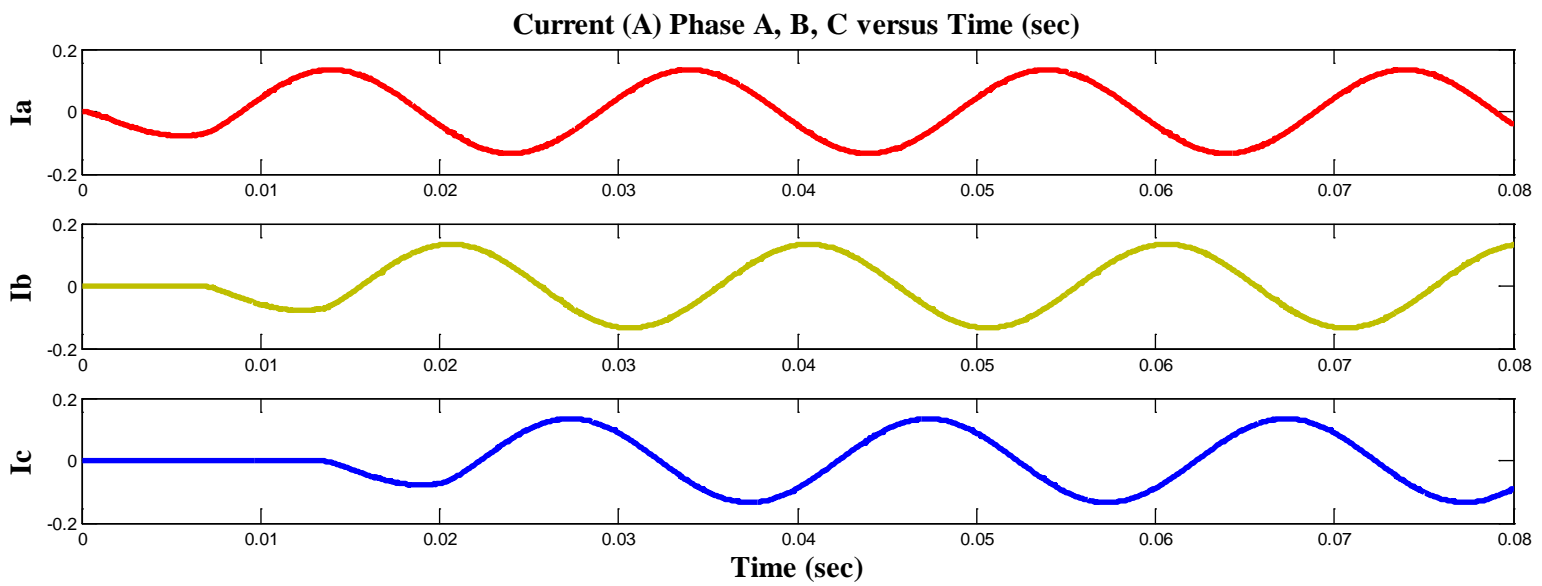

(a)

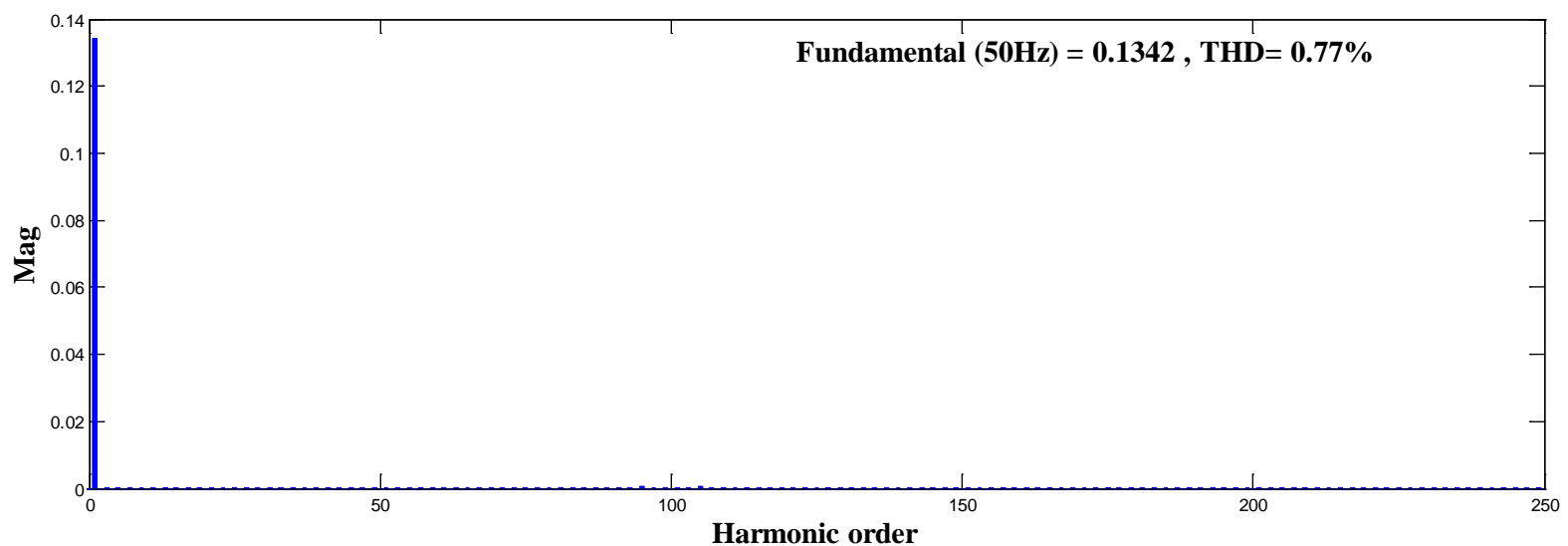

(b)

Figure 11. (a) Three Phase Current (RL load), (b) THD for Phase Current (RL load)
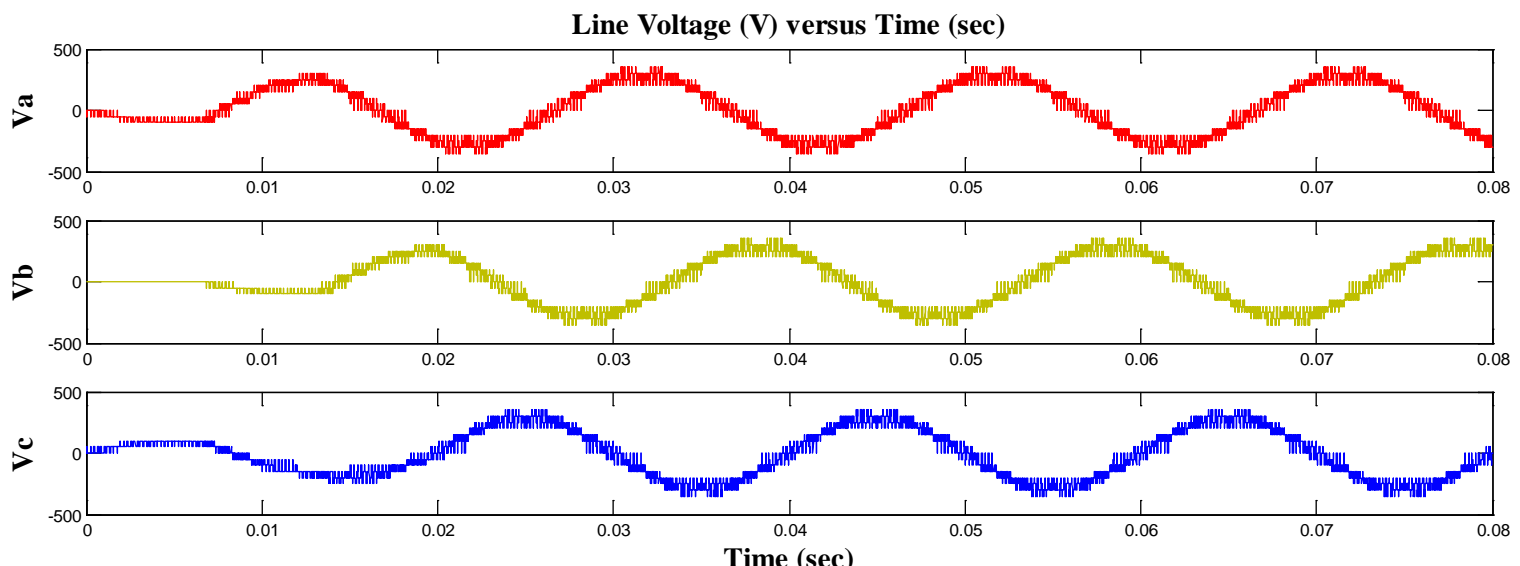

(a) 


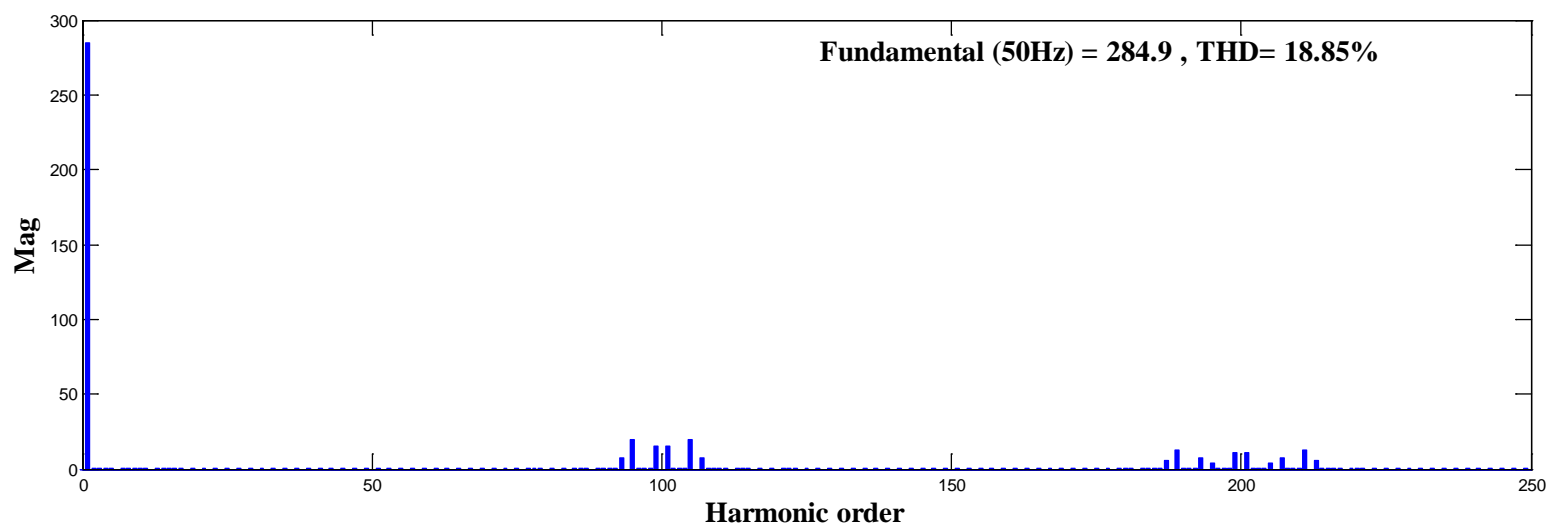

(b)

Figure 12. (a) Line-to-neutral Voltage (RL load), (b) THD for Phase Voltage (RL load)

\subsection{RC load with Unipolar PWM Technique}

The three legs of phase A, B and C of the three phase inverters are connected to R load $(100 \Omega)$ and $\mathrm{C}$ load $(30 \mu \mathrm{F})$ respectively. Fig. 13 and 14 show, the three phases of currents, voltages and total harmonic distortion of current and voltage.
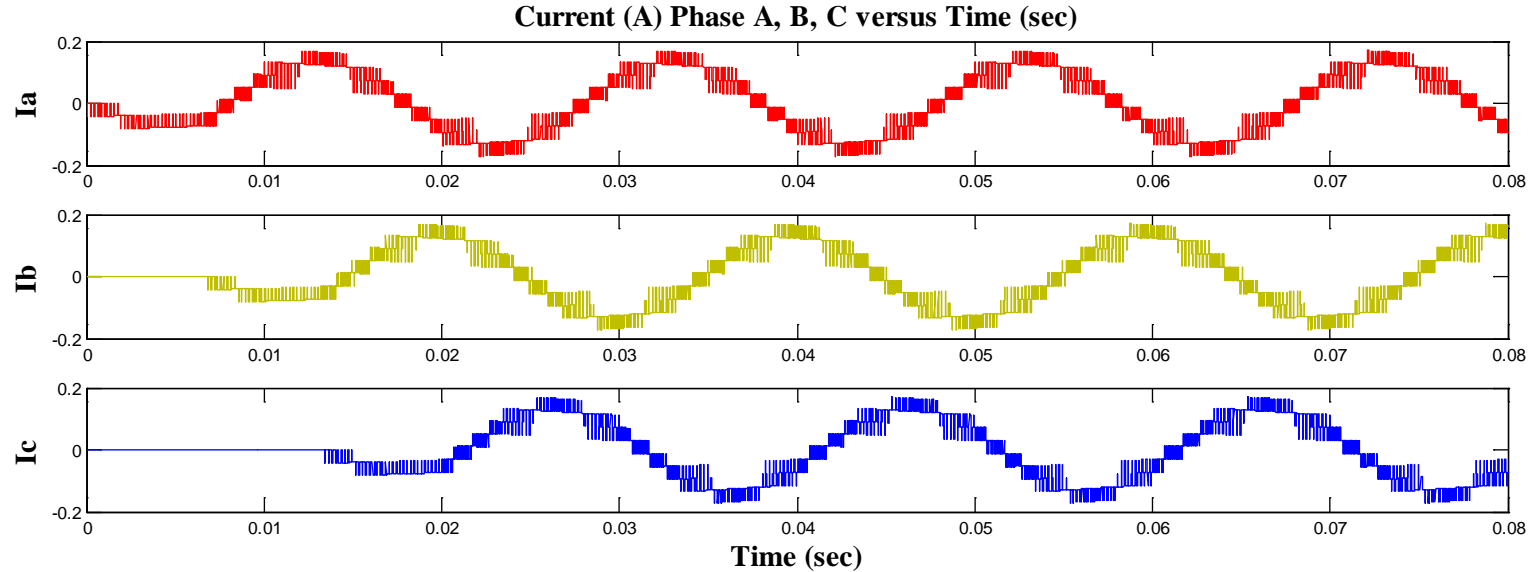

(a)

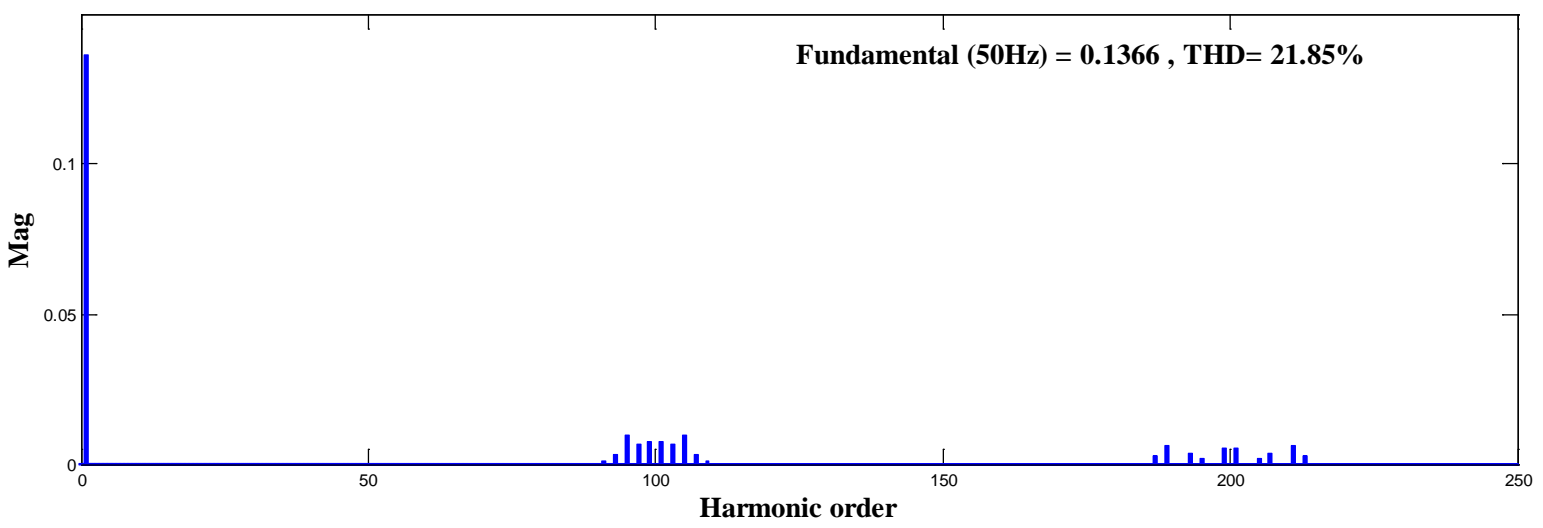

(b)

Figure 13. (a) Three Phase Current (RC load), (b) THD for Phase Current (RC load) 

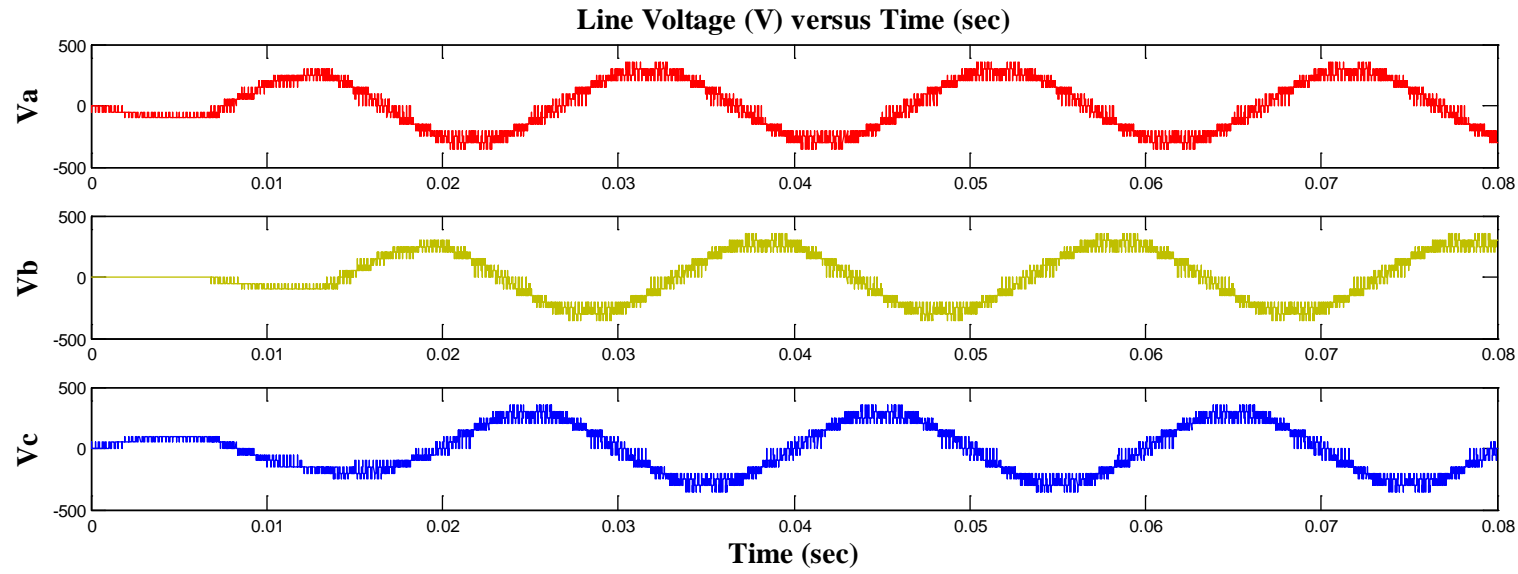

(a)

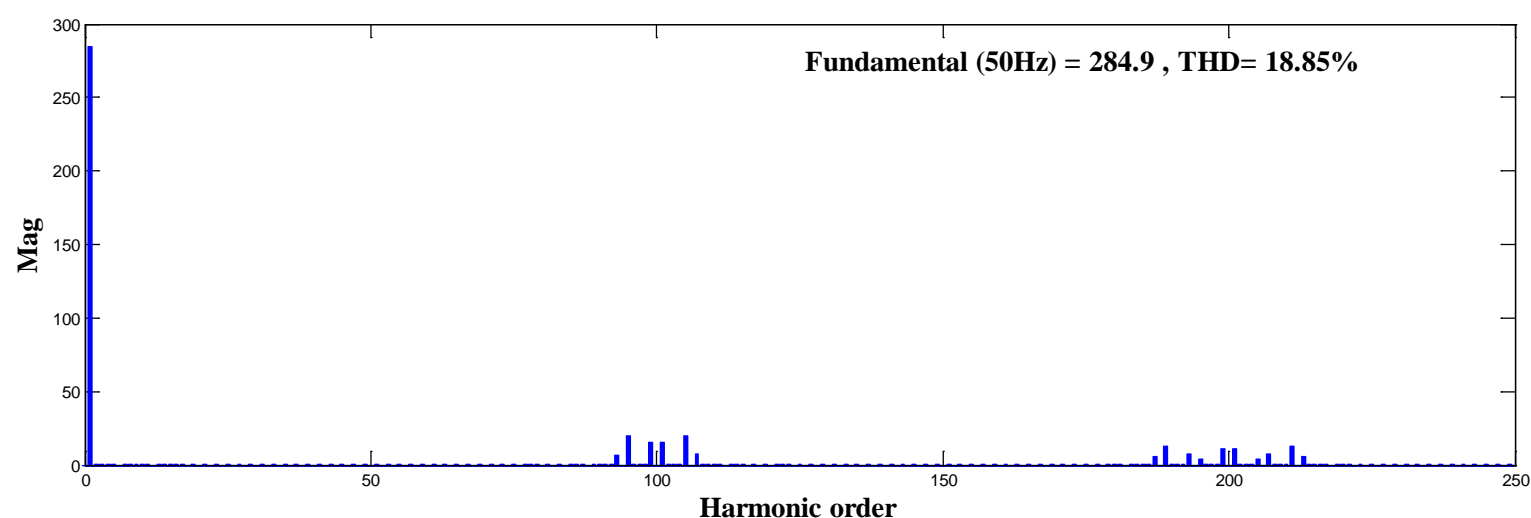

(b)

Figure 14. (a) Line-to-neutral Voltage (RC load), (b) THD for Phase Voltage (RL load)

\subsection{R load with Bipolar PWM Technique}

Each leg of inverters is connected to R load $(100 \Omega)$ and dc voltage (100V). The results waveforms of the three phase currents, voltages and total harmonic distortion of current and voltage for R load are shown in Figs.15 and 16.
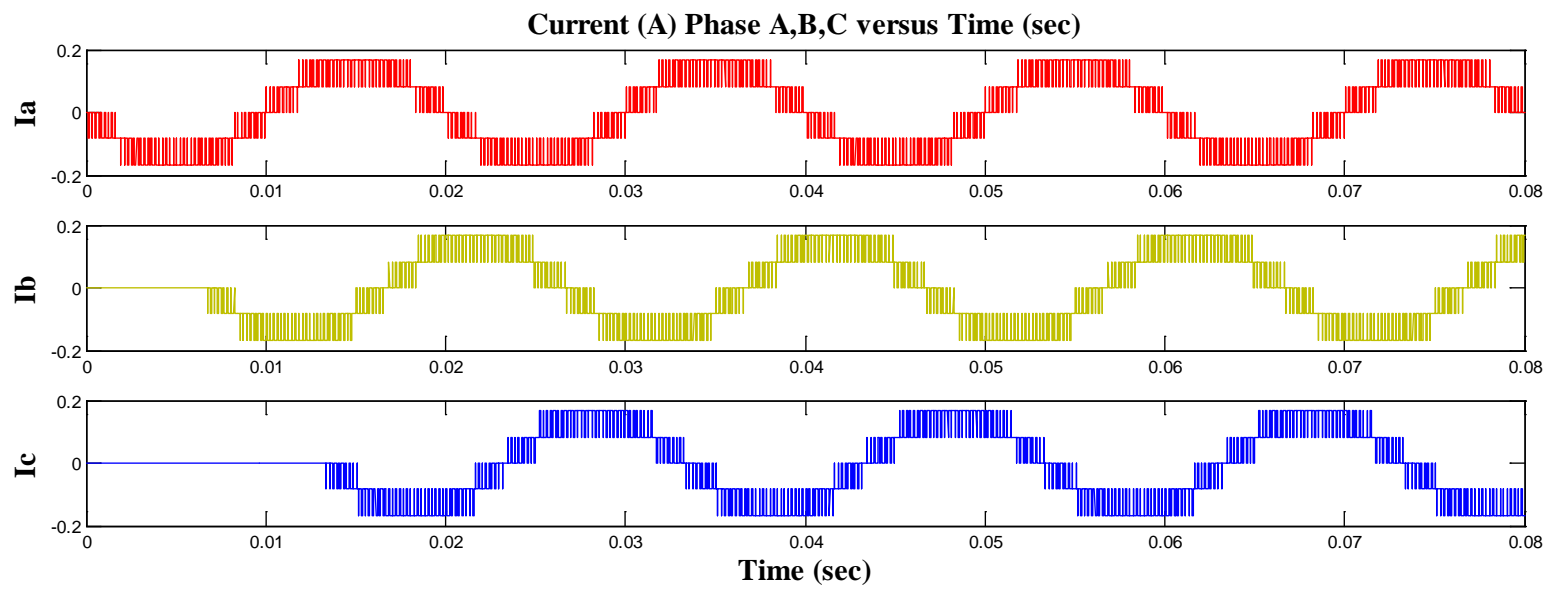

(a) 


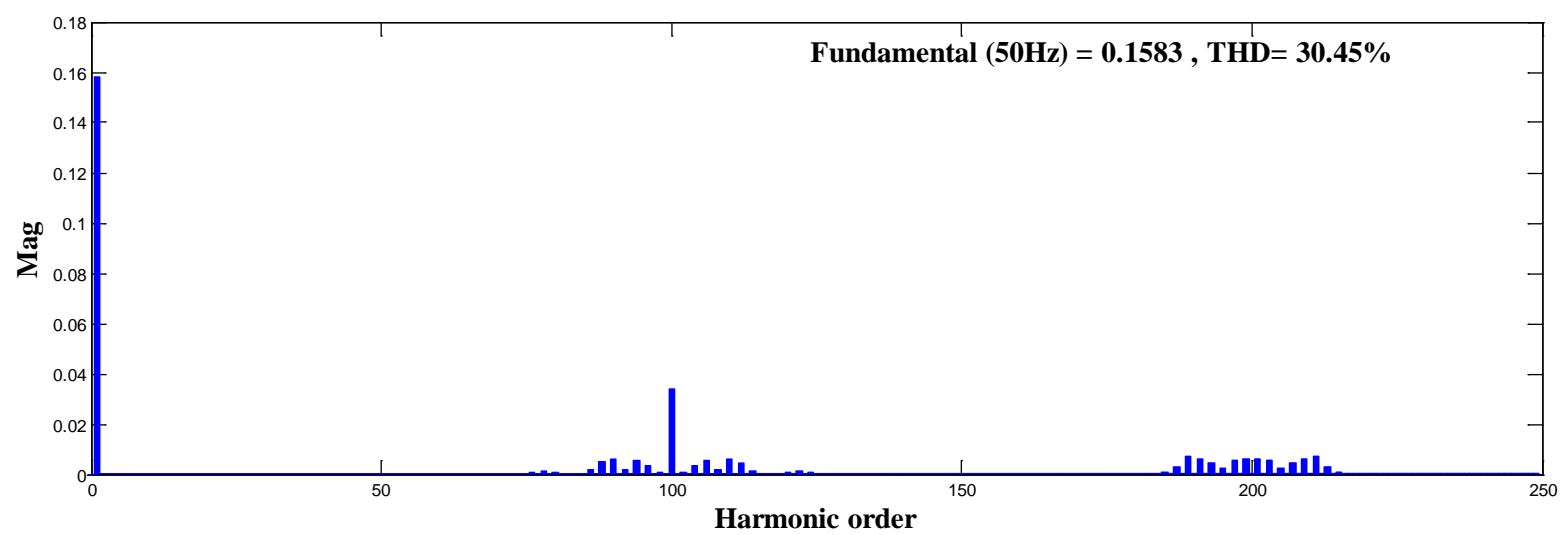

(b)

Figure 15. (a) Three Phase Current (R load), (b) THD for Phase Current (R load)
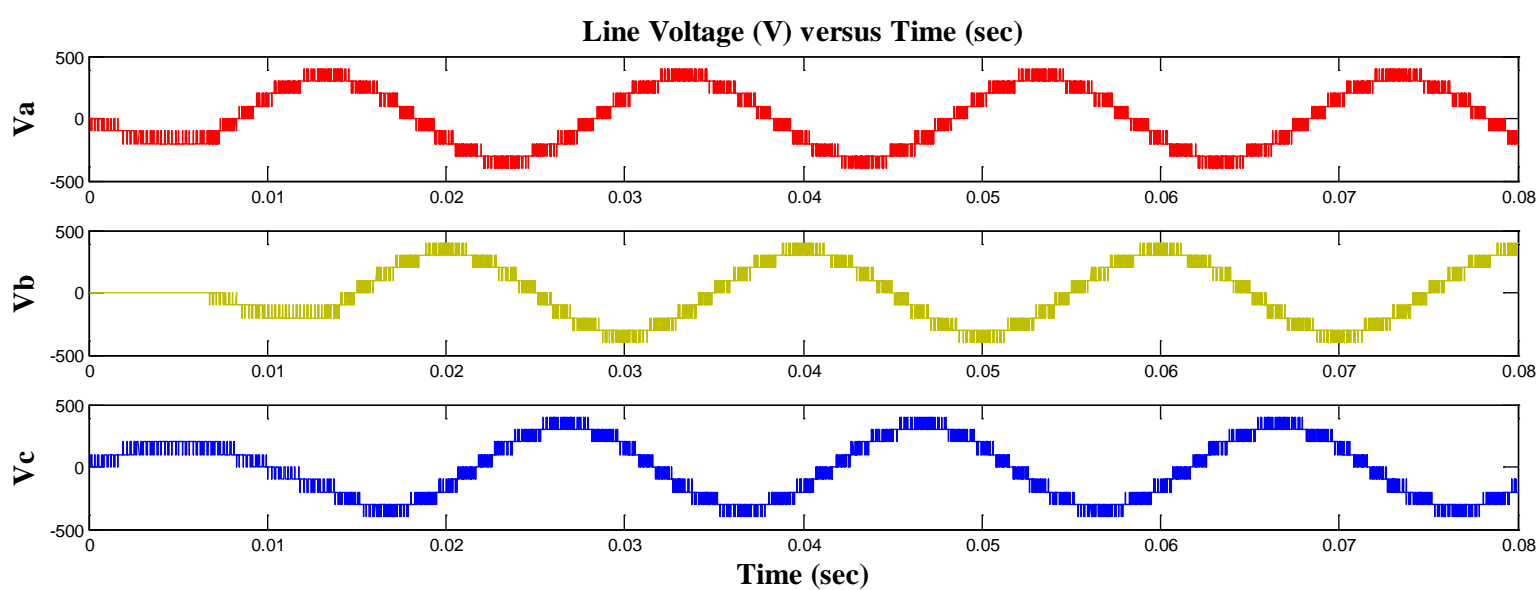

(a)

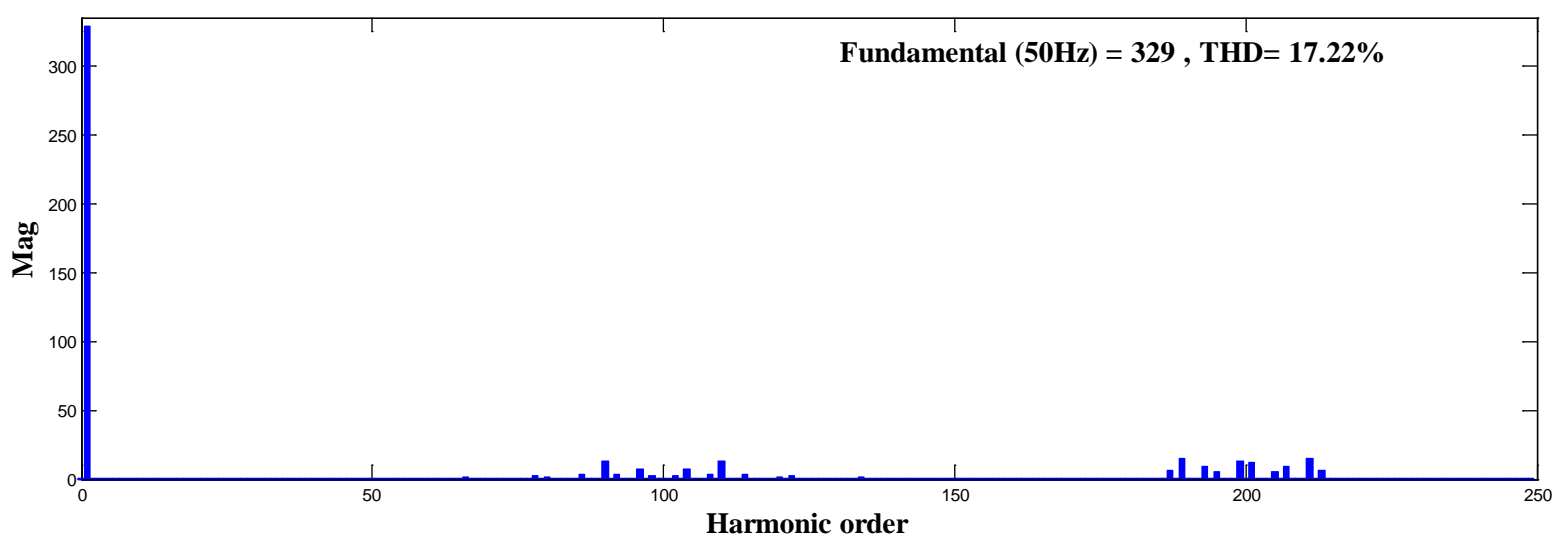

(b)

Figure 16. (a) Line-to-neutral Voltage (R load), (b) THD for Phase Voltage (R load)

\subsection{RL load with Bipolar PWM Technique}

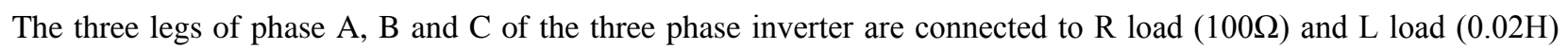
respectively. The three phase currents and voltages are plotted respectively as well as the total harmonic distortion of current and voltage as shown in Figs. 17 and 18. 

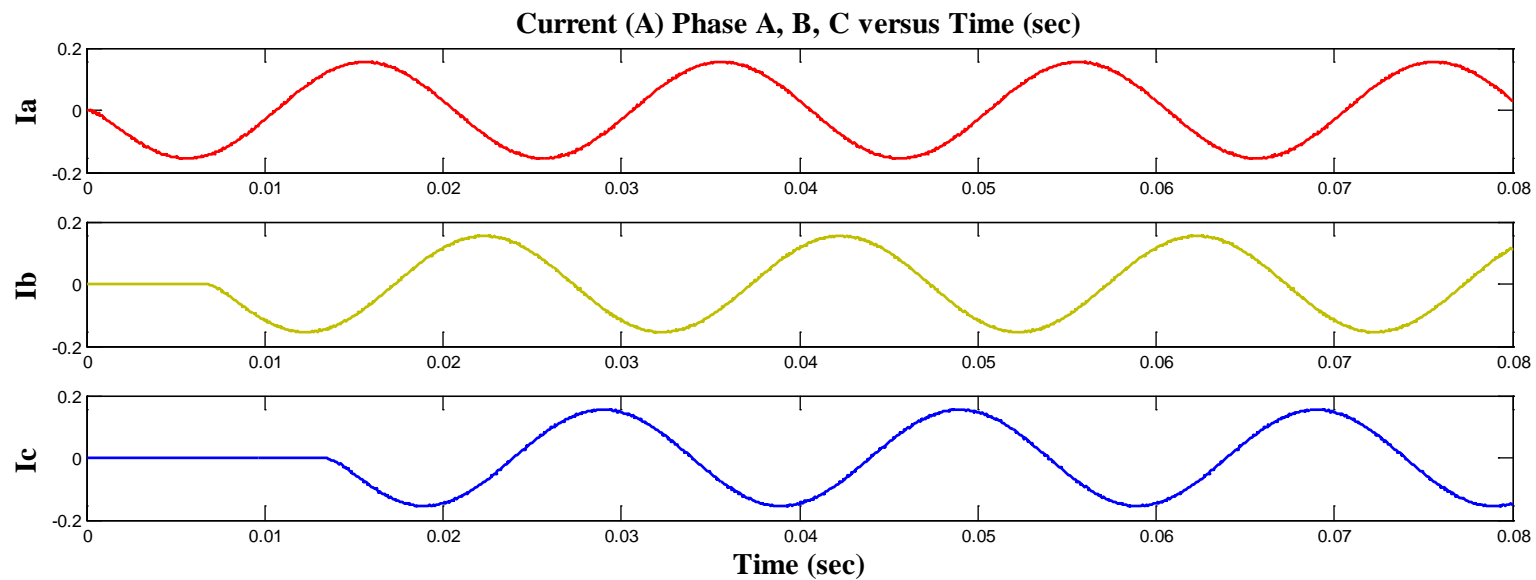

(a)

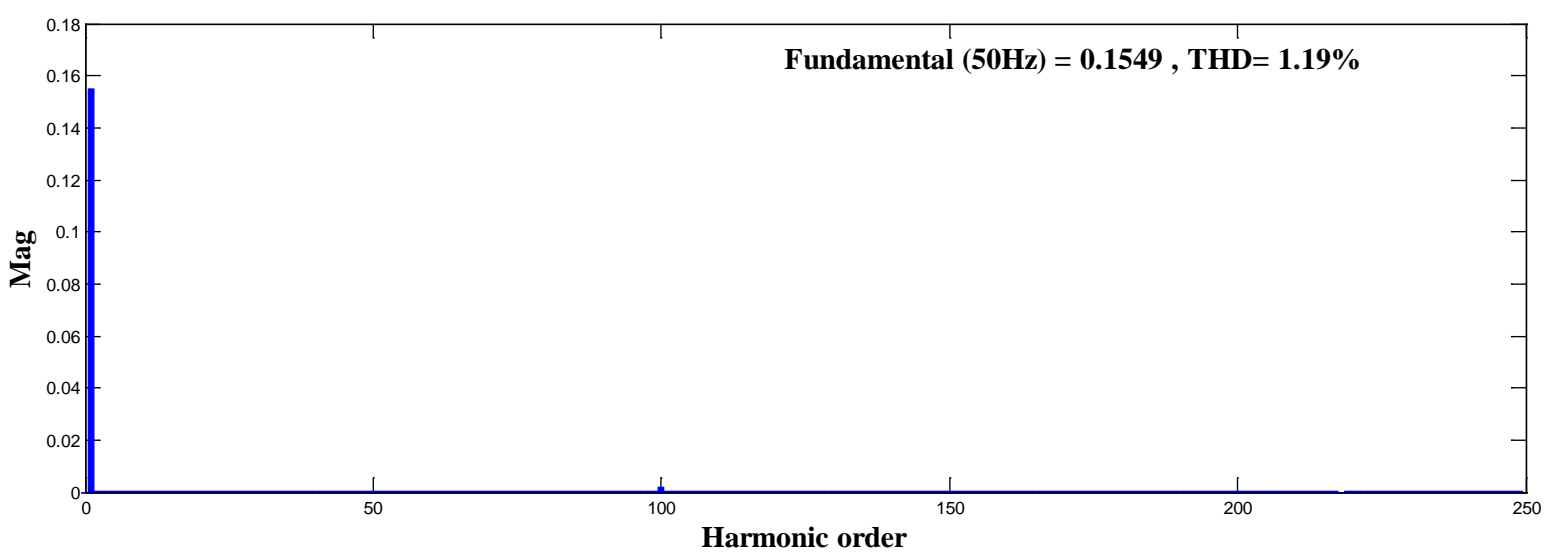

(b)

Figure 17. (a) Three Phase Current (RL load), (b) THD for Phase Current (RL load)
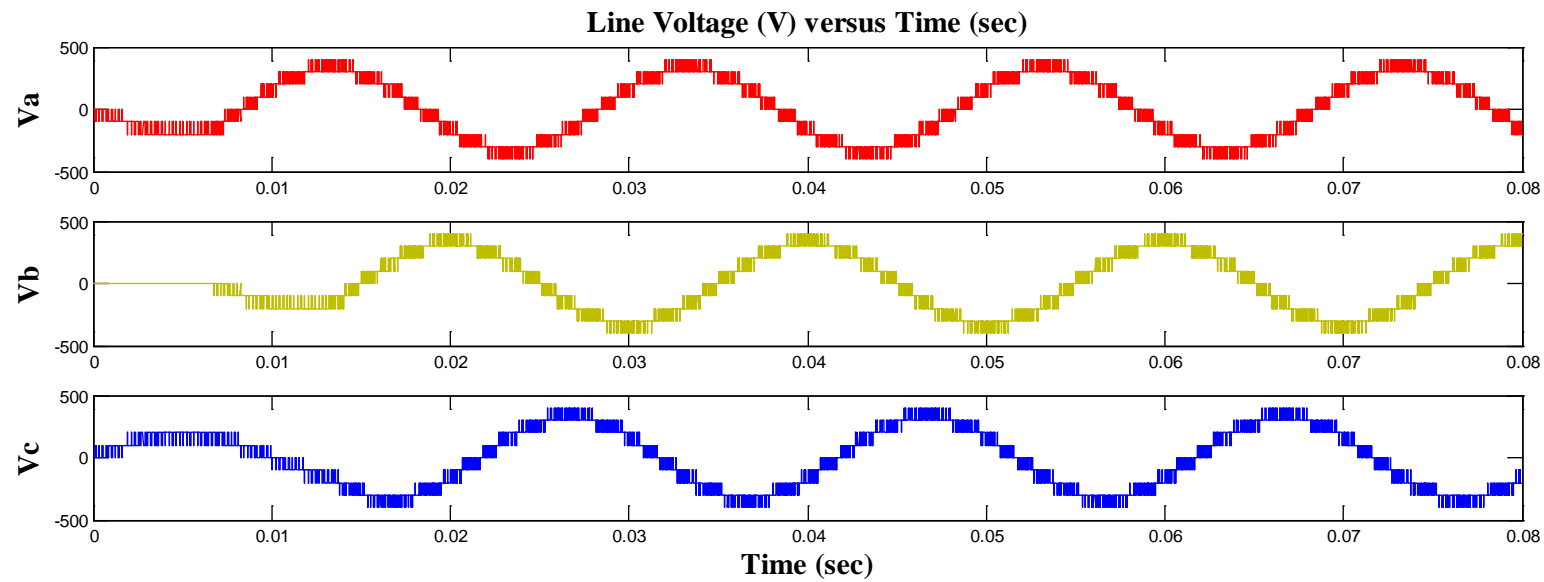

(a) 


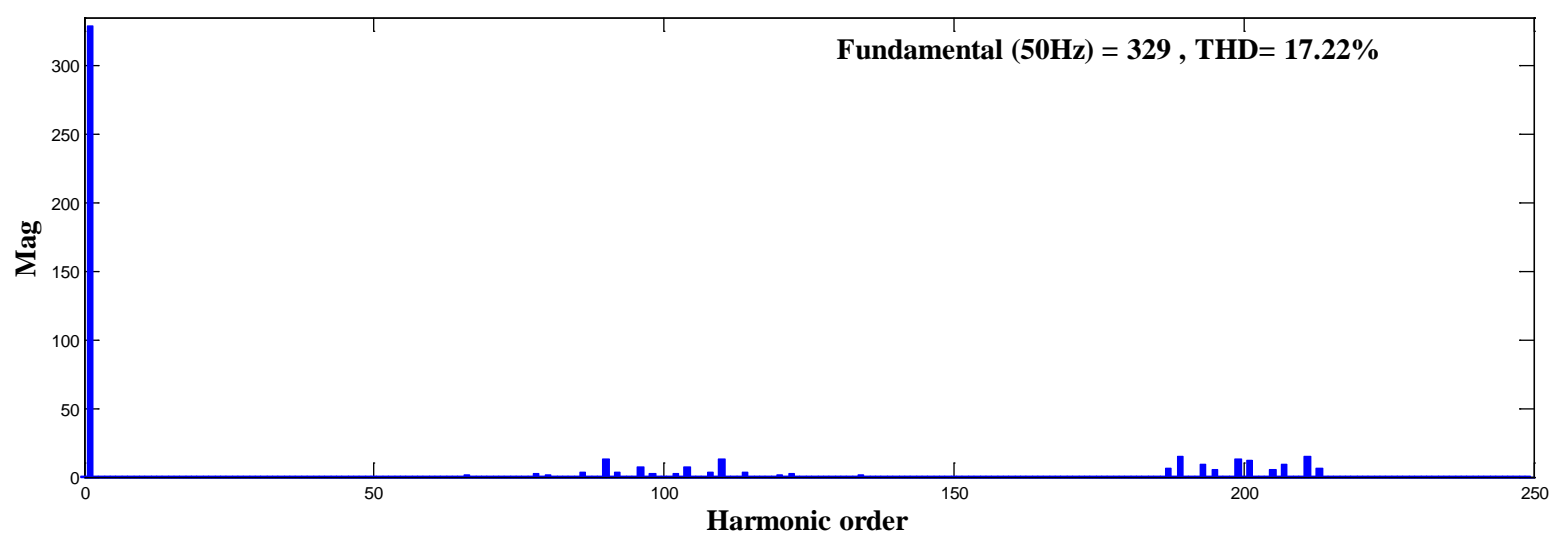

(b)

Figure 18. (a) Line-to-neutral Voltage (RL load), (b) THD for Phase Voltage (RL load)

\subsection{RC load for Bipolar PWM Technique}

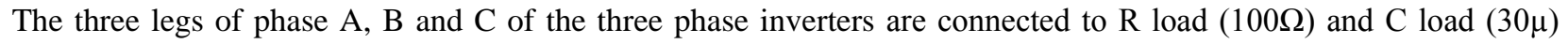
respectively. Fig.19 and Fig. 20 show the three phase currents, voltages and total harmonic distortion of output current and voltage.
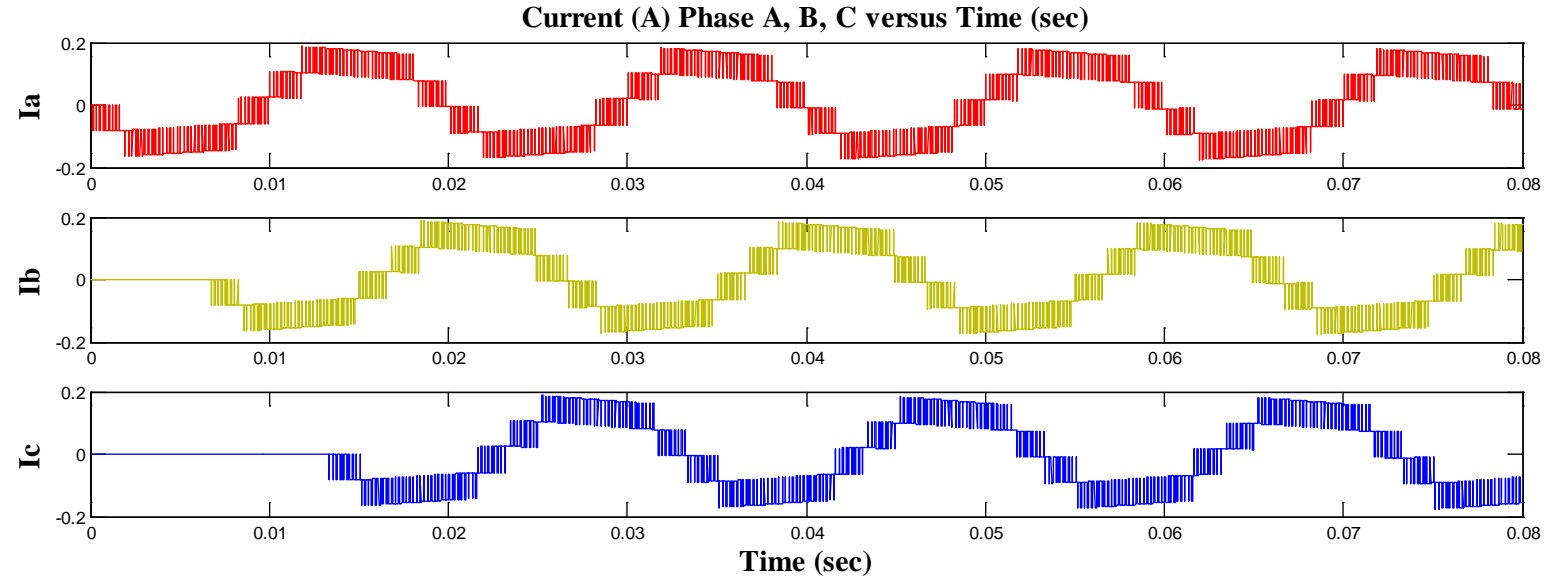

(a)

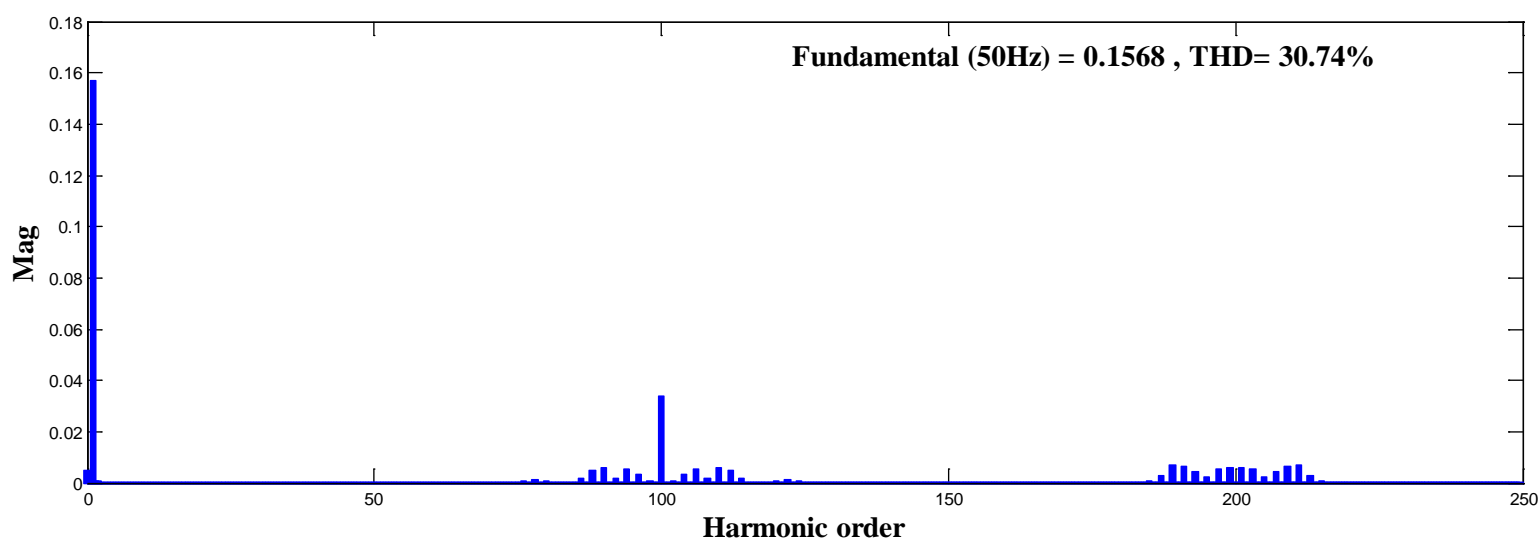

(b)

Figure 19. (a) Three Phase Current (RC load), (b) THD for Phase Current (RC load) 

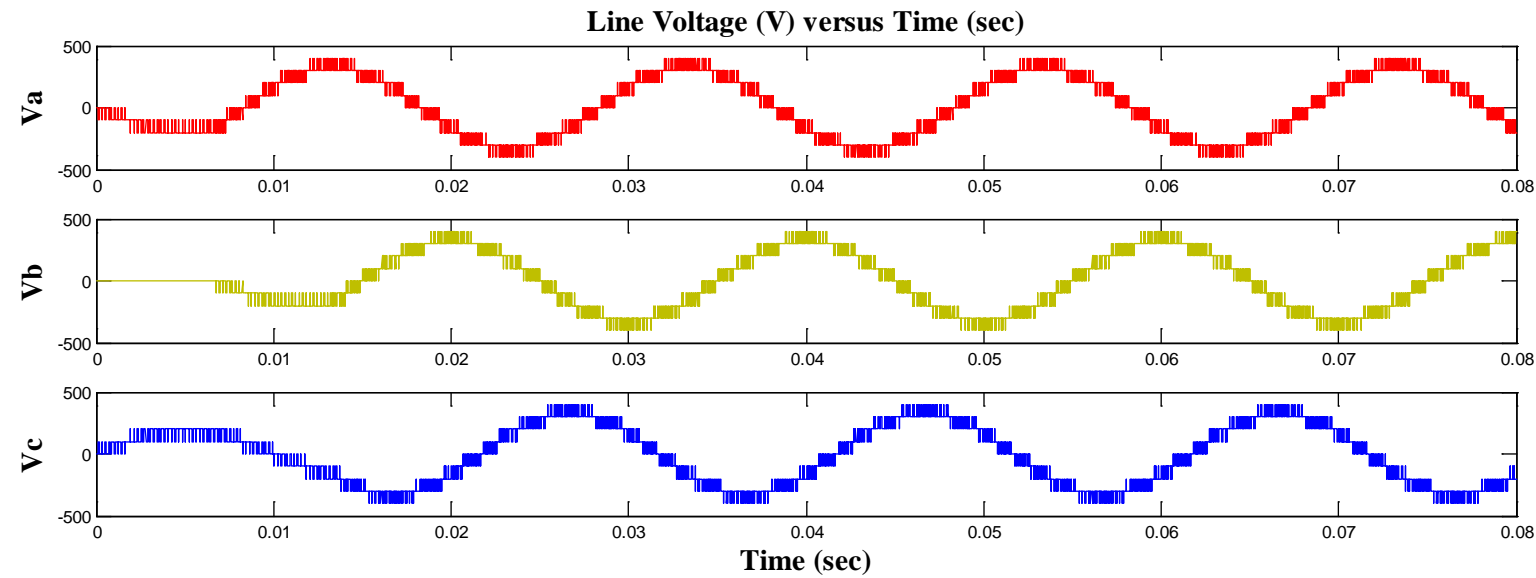

(a)

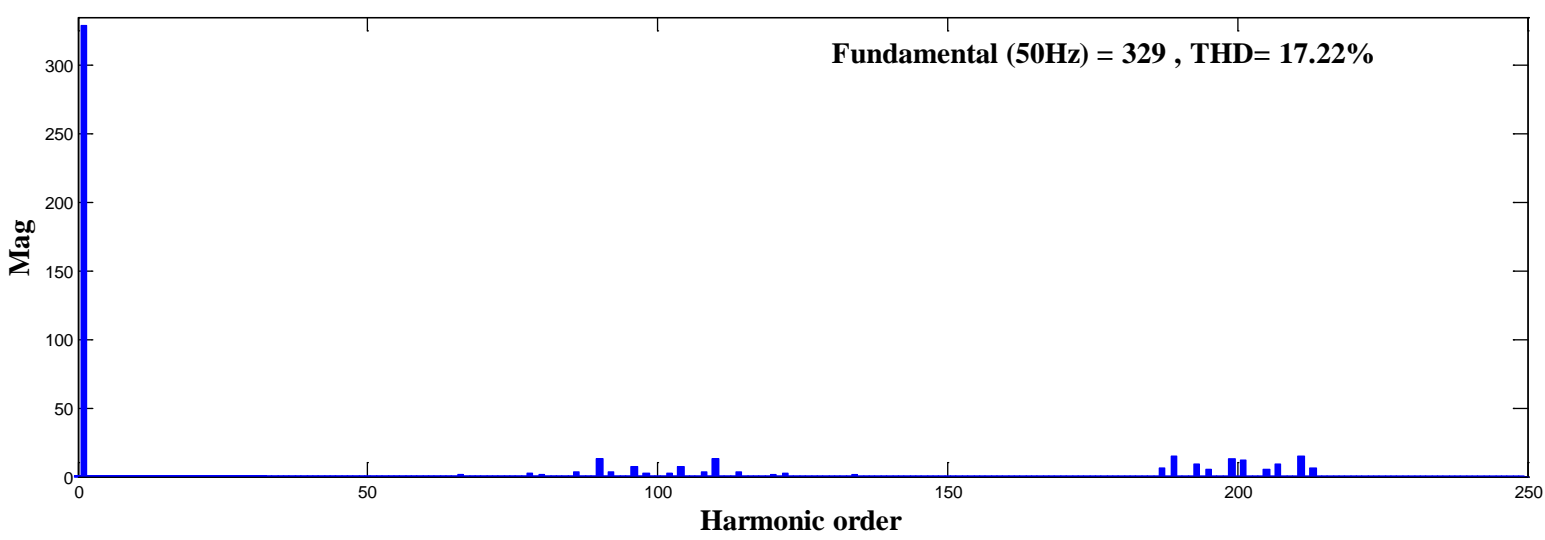

(b)

Figure 20. (a) Line-to-neutral Voltage (RC load), (b)THD for Phase Voltage (RL load)

Table 2. Voltage and current harmonics for unipolar and bipolar PWM techniques

\begin{tabular}{ccccc}
\hline \multirow{2}{*}{ Load } & \multicolumn{2}{c}{ Unipolar } & \multicolumn{2}{c}{ Bipolar } \\
\cline { 2 - 5 } & $\mathrm{THD}_{\mathrm{i}}$ & $\mathrm{THD}_{\mathrm{v}}$ & $\mathrm{THD}_{\mathrm{i}}$ & $\mathrm{THD}_{\mathrm{v}}$ \\
\hline $\mathrm{R}$ & $21.78 \%$ & $18.85 \%$ & $30.45 \%$ & $17.22 \%$ \\
\hline $\mathrm{RL}$ & $0.77 \%$ & $18.85 \%$ & $1.19 \%$ & $17.22 \%$ \\
\hline $\mathrm{RC}$ & $21.85 \%$ & $18.85 \%$ & $30.74 \%$ & $17.22 \%$ \\
\hline
\end{tabular}

Table 2 illustrated the harmonics of seven level three phase inverter. Referring to unipolar harmonics results the three types of non-linear loads has the same voltage harmonic which is $18.85 \%$. However, in current harmonic, RL has the lowest percentage which is $0.77 \%$. RC load has the highest current harmonic which is $21.85 \%$ compared to $\mathrm{R}$ load which is $21.78 \%$. Meanwhile for Bipolar harmonics result the three types of non-linear loads have the same voltage harmonic which is $17.22 \%$. However, in current harmonic, RL has the lowest percentage which is $1.19 \%$. RC load and has the highest current harmonic which is
$30.74 \%$ compared to $\mathrm{R}$ load which is $30.45 \%$.

\section{Conclusions}

From the simulation results of each type of non-linear loads, it is clear that unipolar nine level inverter has the lowest voltage and current harmonics. RL load has the lowest current harmonic because it is a low-pass filter and able to filter low harmonic frequency. Multilevel inverter is able to reduce the harmonic contents. Hence, unipolar switching scheme for multilevel inverter is better than the bipolar switching schemes. In summarizing the comparisons of voltage and current harmonics by using unipolar and bipolar switching schemes, it can be seen that the uniipolar switched inverter has lower harmonic than biipolar switched inverter especially in RL load testing. In unipolar switched inverter, the current harmonic is $0.77 \%$ while bipolar switched inverter is 1.19\%. 


\section{Acknowledgements}

The authors would like to thank and acknowledge to the Universiti Teknikal Malaysia Melaka (UTeM) for Research Grant no.PJP/2018/FKE(6B)/S01607 and Faculty of Electrical Engineering for providing the facilities and financial supports to make the research success.
[13] M. Y. Lada, N. S. Man, G. C. Kim, I. Bugis, "Modeling and Analysis Performance of Three Phase Seven Level Cascaded Multilevel Inverter Using Unipolar Switching Schemes", The 2nd Power and Energy Conversion Symposium 2014 (PECS2014), Melaka, 12 Mei 2014, pp 303-308

\section{REFERENCES}

[1] Hart, D.W. Power electronic, Mcgraw Hill Companies, Americas,NY, 2011

[2] Rhaman, K., Tariq, A, \& Ilahi Bakhash, F, "Modelling and analysis of multilevel inverter using unipolar and bipolar switching schemes,” 2012.

[3] Salehi, Reza, et al. "Elimination of low order harmonics in multilevel inverters using genetic algorithm." Journal of Power Electronics 11.2 (2011): 132-139.

[4] Colak, I., Kabalci E. \&Bayindir R, "Review of multilevel voltage source inverter topologies and control schemes,'’2010.

[5] T.Prathiba,P.Renuga, "A comparative study of total harmonic distortion in multilevel inverter topologies, ", 2012

[6] W.Bin , High power converters and ac drives, John Wiley \& Sons, Inc., Hoboken, New Jersey, 2006.

[7] M. Y. Lada, I. Bugis, and M. Talib, "Simulation a shunt active power filter using MATLAB/Simulink," Power Engineering and Optimization Conf. (PEOCO2010), no. June, 2010, pp. 23-24.

[8] M. Y. Lada, O. Mohindo, A. Khamis, J. M. Lazi, and I. W. Jamaludin, "Simulation single phase shunt active filter based on $\mathrm{p}-\mathrm{q}$ technique using MATLAB/Simulink development tools environment," 2011 IEEE Applied Power Electronics Colloquium (IAPEC), Apr. 2011, pp. 159-164.

[9] Ashok, B., and Rajendran, A. (2013). Selective Harmonic Elimination of Multilevel Inverter using SHE PWM Technique. International Journal of Soft Computing and Engineering (IJSCE), 3(2), 79-82.

[10] Bharath, R. \& Arun V. (2012). 9-Level Trinary DC Source Inverter Using Embedded Controller. IOSR Journal of Engineering (IOSRJEN), 2(10), 90-95.

[11] Colak, I., Kabalci, E., \& Bayindir, R. (2011). Review of Multilevel Voltage Source Inverter Topologies and Control Schemes. Energy Conversion and Management, 52(2), 1114-1128.

[12] M. Y. Lada, M. S. A. Khiar, S. A. Ghani, M. R. M. Nawawi, A. S. M. Nor, J. G. M. Yuen, "Performance Analysis of SHE-PWM using Fourier Series and Newton- Raphson Analysis", International Conference on Mathematics, Engineering \& Industrial Application 2014 (ICoMEIA2014), The Gurney Resort Hotel \& Residences Penang, 28th - 30th May 2014. 